\title{
IMPACT OF RECURRENT AIRWAY OBSTRUCTION (RAO) ON SELECTED ANTIOXIDANTS IN HORSES
}

\author{
Hieronim Borowicz ${ }^{1}$, Krzysztof Kubiak ${ }^{1}$, Goran Nikolovski², Artur Niedźwiedź ${ }^{1}$ \\ ${ }^{1}$ Department of Internal Diseases with Clinic for Horses, Dogs and Cats, \\ Faculty of Veterinary Medicine, Wroclaw University of Environmental and Life Sciences, \\ Pl. Grunwaldzki 47, 50-366 Wroclaw, Poland \\ ${ }^{2}$ Department of Internal Diseases for Pet Animals and Equides, \\ Faculty of Veterinary Medicine, Lazar Pop Trajkov 5-7, 1000 Skopje, Macedonia \\ Received 6 July 2015; Received in revised form 9 December 2015; Accepted 18 January 2016
}

\begin{abstract}
The aim of this review was to collect the most important data on the characteristics of selected antioxidants in horses with recurrent airway obstruction (RAO). RAO is one of the most common respiratory diseases in horses. This disease can not be cured, but we can try to stop its progression. It is not exactly known, what is the real contribution of antioxidants in the pathology of recurrent airway obstruction. Many researchers investigated the possibility of using antioxidant supplementation in horses with RAO.
\end{abstract}

Key words: recurrent airway obstruction, antioxidants, horses

\section{INTRODUCTION}

Recurrent airway obstruction in horses (RAO), otherwise known as heaves, is one of the most common pathology of the respiratory system of horses. Its previous name Chronic Obstructive Pulmonary Disease (COPD) derived from human medicine, defines the symptoms characteristic for smokers and inaccurately refers to a disease occurring in horses. This is due to the pathophysiology of the disease and its different course. RAO is a disease that occurs in middle-aged horses, consisting of inflammation and gradual bronchospasm with bronchial walls rebuilding, and excessive production of mucus (1). It occurs most commonly in horses kept in stables, exposed to dust and fed low-quality hay. RAO occurs in horses aged

Corresponding author: Prof. Artur Niedźwiedź, $\mathrm{PhD}$

E-mail address: artur.niedzwiedz@up.wroc.pl

Present address: Department of Internal Diseases,

Faculty of Veterinary Medicine, Wroclaw University of Environmental and Life Sciences, Pl. Grunwaldzki 47, 50-366 Wroclaw, Poland

Phone: +48501272377

Copyright: (C) 2016 Borowicz H. This is an open-access article published under the terms of the Creative Commons Attribution License which permits unrestricted use, distribution, and reproduction in any medium, provided the original author and source are credited.

Competing Interests: The authors have declared that no competing interests exist.

Available Online First: 1 February 2016

Published on: 15 March 2016

http://dx.doi.org/10.1515/macvetrev-2016-0074 seven years and over, and the incidence increases with age. Some authors considered the genetic background as a predisposing factor, which results from the fact that in some breeding lines RAO is frequently observed $(2,3)$.

Aerobic organisms use oxygen for their metabolism, therefore they need to develop a number of mechanisms to prevent excessive formation of reactive oxygen species (ROS). Studies on free radicals began in 1954, when Commoner et al. (4) published a study on ROS. Another groundbreaking report, regarding the participation of free radicals in the aging process is authored by Harman (5). In thee sixties superoxide dismutase (SOD) was discovered, which is an enzyme neutralizing superoxide anion $\left(\mathrm{O}_{2}^{-}\right)$, (6). Reactive oxygen species are involved in many cellular processes, but their excessive quantity leads to oxidative stress, which manifests itself by damage to proteins, nucleic acids and lipids. The role of antioxidants is played by fully specialized enzymes and low molecular weight non-enzymatic antioxidants. The body's defense mechanisms against free radicals include: preventing the formation of ROS and their reactions with biologically important compounds (prevention), interrupting the free radical chain reaction and undesirable non-radical oxidation (termination and intervention) and removing the effects of ROS 
reactions with biomolecules (elimination or repair). The first line of defense is the so-called enzymatic triad (Fig. 1), i.e. superoxide dismutase (SOD), glutathione peroxidase (GPx), and catalase (CAT) as well as the proteins binding the transition metals (7).
A significant contribution of reactive oxygen species to a number of lung diseases in humans has been confirmed (11), among others, to acute respiratory distress syndrome (12), asthma (13) and chronic bronchitis (14). Horses are one of the alternative models for human asthma (15)

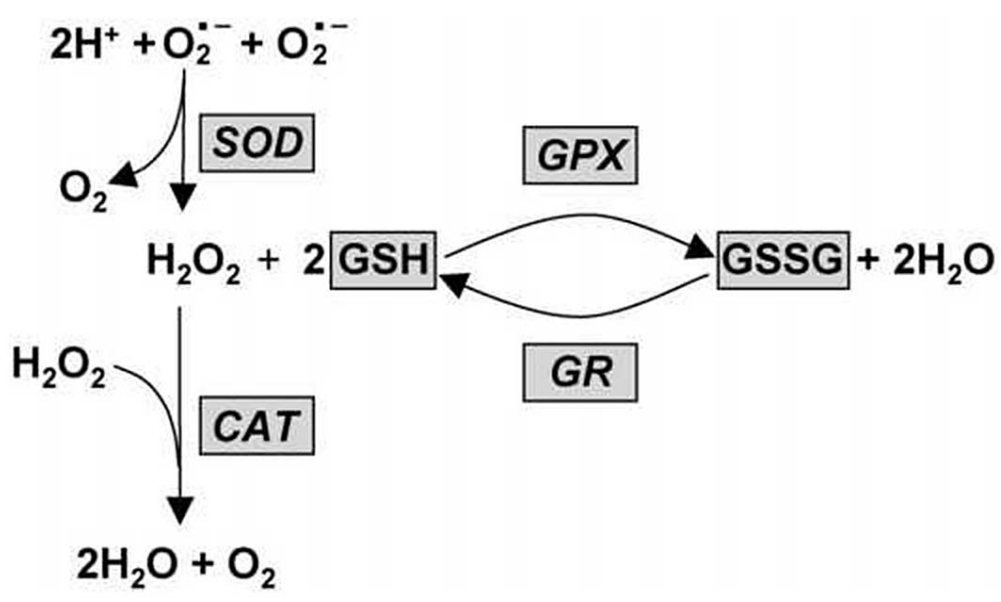

Figure 1. Diagrammatic representation of the relationship between antioxidant enzymes, GSH and GSSG. SOD, Superoxide dismutase; CAT, cat-alase; GPX, glutathione peroxidase; GR, glutathione reductase; GSH, reduced glutathione; GSSG, oxidized glutathione

SOD is an enzyme that alternately catalyzes the dismutation (or partitioning) of the superoxide $\left(\mathrm{O}_{2}^{-}\right)$radical into either ordinary molecular oxygen $\left(\mathrm{O}_{2}\right)$ or hydrogen peroxide $\left(\mathrm{H}_{2} \mathrm{O}_{2}\right)$. Superoxide is produced as a by-product of oxygen metabolism and, if not regulated, causes many types of cell damage. Hydrogen peroxide is also damaging and is degraded by other enzymes such as catalase. Thus, SOD is an important antioxidant defense in nearly all living cells exposed to oxygen. CAT catalyzes the decomposition of hydrogen peroxide to water and oxygen (8). It is a very important enzyme in protecting the cell from oxidative damage by reactive oxygen species (ROS). Likewise, catalase has one of the highest turnover numbers of all enzymes; one catalase molecule can convert approximately 5 million molecules (9) of hydrogen peroxide to water and oxygen each second. GPx is the general name of an enzyme family with peroxidase activity whose main biological role is to protect the organism from oxidative damage (10). The biochemical function of glutathione peroxidase is to reduce lipid hydroperoxides to their corresponding alcohols and to reduce free hydrogen peroxide to water. The second line of defense mainly involves low molecular weight antioxidants, or free radical scavengers. The third line of defense against oxidative stress is the ROS reaction with cellular macromolecules.

6
(Table 1, Table 2). Studies on the body's response to the ROS in the case of human respiratory diseases are well known. Research on oxidative stress in horses with RAO has been conducted previously, although ambiguous results have been reported $(16,17)$. Moreover, most of the studies relate to the local effects of oxidative stress in the airways. Only a few studies investigated systemic markers of oxidative stress in RAO-affected horses. Results from these studies are difficult to compare because of differences in methodologies used and type of biomarker investigated. Despite the diversity of research models, namely exposing animals to allergens or factors having a negative impact on the body or subjecting them to stress tests, the studies did not allow for an in-depth analysis of the body's response to the negative effects of oxidative stress in RAO $(16,17,18)$.

\section{GLUTATHIONE LEVEL IN RAO CRISIS}

Art et al. (19) noted that the exacerbation of RAO in horses caused significant changes in the lungs, including changes in the number of neutrophils in bronchoalveolar lavage (BAL). Research on reduced glutathione levels (GSH), glutathione disulfide (GSSG) and glutathione redox ratio (GRR) in the blood showed no significant differences between 
Impact of recurrent airway obstruction (RAO) on selected antioxidants in horses

Table 1. Horse as alternative model of human asthma

\begin{tabular}{|c|c|}
\hline \multicolumn{2}{|c|}{ Characteristics and Approaches of the Functional and Inflammatory Response to Allergen Exposure } \\
\hline Early Phase Bronchoconstriction & No \\
\hline Late Phase Bronchoconstriction & Yes \\
\hline Bronchial Hyperresponsiveness & Yes \\
\hline $\begin{array}{c}\text { Bronchoalveolar Lavage or Bronchial Brushing } \\
\text { Markers in Exhaled Breath Condensate Detected in } \\
\text { Response to Allergen Exposure }\end{array}$ & $\mathrm{H}_{2} \mathrm{O}_{2}$ \\
\hline Characteristics and Approaches of the Structural Response to (Repeated) Allergen Exposure \\
\hline Radiography & Yes \\
\hline Computed Tomography & No \\
\hline Biopsy & Yes \\
\hline Post-Mortem Histology & Yes \\
\hline
\end{tabular}

the group of healthy horses, horses with RAO in remission and those in acute phase of the disease. On the other hand, the values of those indicators measured in bronchoalveolar lavage fluid were significantly higher in horses with RAO in acute phase compared to healthy horses. There was also a significant correlation between the GRR, GSSG and neutrophil counts. These studies seem to confirm the hypothesis that oxidative stress is a secondary phenomenon to the increase in the number of neutrophils in the lower respiratory tract, which is associated with inflammation. Olszewski and Laber (20) confirmed the primary role of neutrophils, which are most stimulated among all the cells when animals are in acute phase. Art et al. (19) presented interesting relationship between the level of GSSG and GSH, because the increase in the level of GSSG should be followed by a decrease in the level of GSH. However, in their research the GSH level was high. This mechanism may be associated with increased release of the intracellular GSH type II pneumocytes due to increased membrane permeability, cell lysis or active transport (21).

\section{PHYSICAL EFFORT ANTIOXIDANTS LEVEL \\ AND \\ THE}

A research conducted by Kirschvink et al. (22) on the impact of chronic airway inflammation and physical effort on antioxidant status of horses with RAO showed both systemic and localized changes in the values of antioxidants. Difference of GSH, GSSG and GRR levels in blood of healthy horses and those with RAO, measured after physical effort was significant. The increase in these values suggests that systemic RAO glutathione synthesis is enhanced. The level of uric acid (UA) in horses with RAO after physical effort was significantly higher compared to healthy horses. The reduced ability to deliver oxygen during exercise increases oxygen deficit, which is associated with obtaining energy through anaerobic respiration. Its consequence is the accumulation of uric acid (23). Levels of markers of antioxidant status obtained from bronchoalveolar lavage were more diverse than those measured in the blood. This could be related to difficulties in standardizing the methods of collection. Horses with RAO in remission had similar values of GSH, GSSG and GRR and even exercise did not significantly change their values. These results are consistent with previous studies concerning dysregulation of GSH synthesis in the lung in horses with RAO (19), and people with asthma $(24,25)$. UA levels were higher at rest in horses in acute phase. UA 60 minutes after exercise was significantly higher in healthy horses and horses with RAO in remission. UA concentration was correlated with the percentage of neutrophils in BAL, which may suggest that airway inflammation leads to an increase in the local synthesis of uric acid (26).

\section{EFFECT OF SUPPLEMENTATION}

There are many studies indicating that the consumption of a diet rich in antioxidants may have a beneficial effect on chronic respiratory diseases such as asthma and COPD in humans (27, 28, 29, 30). These reports have been used by Kirschvink et al. (31), who aimed at determining the effect of oral supplementation of antioxidants on the levels of antioxidants in blood and bronchoalveolar lavage fluid in horses. The antioxidant supplement (AS) consisted of a mixture of natural antioxidants including vitamin $\mathrm{E}$, vitamin $\mathrm{C}$ and selenium from a variety of sources (based on Winergy Ventilate Ventil-ate Respiratory Supplement (R) (UK)). The 
placebo consisted of oat feed pellets without additive. Either AS or placebo $(250 \mathrm{~g})$ were fed once daily with $1 \mathrm{~kg}$ wheat concentrate (molassed oats, pressed corn and pellets). The results indicated that the plasma level of UA was significantly lower after the supplementation than before antioxidant $(\mathrm{P}<0.02)$, and placebo $(\mathrm{P}<0.02)$ administration. The exercise caused a statistically significant $(\mathrm{P}<0.05)$ increase in the level of UA in bronchoalveolar lavage fluid in all groups. The increase in plasma levels of UA during and after exercise reflects the loss of adenosine5 '-triphosphate and purine metabolism in muscle, which produces hypoxanthine (32). During intense exercise, xanthine dehydrogenase is converted into xanthine oxidase. This enzyme catalyzes the conversion of hypoxanthine to uric acid and xanthine associated with the release of the superoxide anion. Thus lower level of uric acid is associated with a reduction in purine metabolism, reduction in ROS production and oxidative stress reduction. Mills et al. (33) demonstrated that administration of allopurinol which is an inhibitor of dehydrogenase and xanthine oxidase significantly reduces the synthesis of UA and GSSG in healthy horses during exercise. In people with COPD undergoing physical training, the administration of allopurinol reduced the level of GSSG and malondialdehyde (MDA) (34). Different levels of GSH, GSSG and TGSH obtained in these studies confirmed previous report that chronic inflammation of the respiratory system such as asthma in humans (24) and RAO in horses (19) dysregulates the metabolism of these compounds.

Youssef et al. (35) presented a study in which they evaluate the effect of a combination of sodium selenite and ascorbic acid on clinical outcome, antioxidant enzymes, and trace elements status in horses with lower airway disease. For this purpose, 40 draft horses with lower airway disease were randomly selected. For all groups, each horse was administered antibiotic, non-steroidal antiinflammatory, and mucolytic drug. In addition, 2 groups (each ten horses) were injected with $15 \mathrm{mg} / \mathrm{kg}$ sodium selenite and $30 \mathrm{mg} / \mathrm{kg}$ ascorbic acid every $24 \mathrm{~h}$ for successive 4 weeks. The present result is supported by the suggestion of Kirschvink et al. (36) who reported that the beneficial effect of antioxidants supplementation on the oxidant/ antioxidant equilibrium should only be expected after a few weeks of its supplementation. Regarding the antioxidant enzymes activity, GR activity was significantly decreased after sodium selenite and ascorbic acid supplementation. This result could be attributed to the increased activity of theglutathione antioxidant system as indicative of improved antioxidant potential with subsequent increase of the intracellular synthesis of glutathione. GST and CAT activities were increased after antioxidant supplementation. This act may be due to increase and modulation of cellular glutathione redox system due to sparing effect of vitamin $\mathrm{E}$ on glutathione utilization for the scavenging of lipid peroxidation reactions $(36,37,38)$. In order to confirm the hypothesis that airways inflammation (39) and hyper-responsiveness observed in equine passively sensitized bronchi could be related to an increased production of ROS, Matera et al. evaluated the effects of a pretreatment with GSH on either nonsensitized or passively sensitized bronchi. They observed that a pretreatment with GSH significantly

Table 2. Characteristic of horse lungs according to secondary lobulation

\begin{tabular}{|c|c|}
\hline Lobulation of the lung & $\begin{array}{c}\text { Imperfect development } \\
\text { (incomplete connective tissue septa between } \\
\text { secondary lobules) }\end{array}$ \\
\hline Pleura & $\begin{array}{c}\text { Thick } \\
\text { (and supplied by the bronchial artery) }\end{array}$ \\
\hline Distal airways & $/$ \\
\hline Terminal bronchioles & Present \\
\hline Respiratory bronchioles & $\begin{array}{c}\text { Present } \\
\text { (but poorly developed) }\end{array}$ \\
\hline Collateral airways & Partly present \\
\hline Circulation & $/$ \\
\hline $\begin{array}{c}\text { Termination of the } \\
\text { bronchial artery }\end{array}$ & $\begin{array}{c}\text { Follows the bronchus and artery in the } \\
\text { perishery but departs from these structures } \\
\text { as it approaches the hilum }\end{array}$ \\
\hline $\begin{array}{c}\text { Pulmonary veins } \\
\text { Phunts between bronchial } \\
\text { artery and pulmonary artery }\end{array}$ & \begin{tabular}{c} 
Present \\
\hline
\end{tabular} \\
\hline
\end{tabular}


decreased the IL-1 $\beta$ mRNA expression and the contraction induced in passively sensitized tissues, but did not show any effect in the non-sensitized ones. In order to justify these different responses, we must consider that under normal circumstances ROS are kept under tight control by SOD enzymes (40). In acute and chronic inflammation, the production of ROS increases at a rate that overwhelms the capacity of the endogenous defense system to remove them (40). Moreover, GSH is an important component of the lung antioxidant defense (41). Therefore, a supplementation of this antioxidant agent is necessary to protect lungs from oxidative stress during acute or chronic inflammation. Based on this analysis, it can be confirmed that oral supplementation may have beneficial effects on antioxidant status of horses suffering from RAO.

Seeking an effective remedy for RAO, several agents have recently been tried. The study presented by Venugopal et al. (42) evaluated potential therapeutic agents, namely pentoxifylline, PDTC and endothelin A and B antagonists (in combination), for their effectiveness in reducing reactive species levels in pulmonary tissues. Being a methylxanthine derivative, pentoxifylline is a nonspecific phosphodiesterase inhibitor and has smooth muscle relaxing properties (43). Ammonium pyrrolidinedithiocarbamate is an antagonist that inhibits activation of nuclear factor-kB, a regulator of transcription, which comes later in the inflammatory reactions (44). Upregulation of endothelin receptor function has been reported in airway inflammation $(45,46)$, and blockade of its receptors could have beneficial effects in RAO. As expected, all these agents were effective in reducing ROS in affected horses. However, only pentoxifylline and endothelin antagonists were effective in reducing RNS. The inability of PDTC to reduce peroxynitrite suggests that upstream inhibition of inflammatory changes is needed to control the progression of pulmonary inflammation. The present study agrees with previous reports that pentoxifylline given to RAOaffected horses improved their respiratory function (47), possibly by reducing reactive species stress.

\section{EXPOSURE TO OZONE AND THE ANTIOXIDANTS LEVEL}

Ascorbic acid (AA) is an important, nonenzymatic antioxidant. It reacts with inhaled oxidants, for example, ozone (48) as well as those of neutrophil origin, i.e., hydrogen peroxide or hypochlorous acid (49). Earlier reports indicate potentially beneficial role of ascorbic acid in the treatment of asthma and bronchospasm $(50,51)$. As one of the first Deaton et al. (52) studied the impact of ascorbic acid on the pathology of RAO in horses and inflammation on the body's antioxidant levels. In these studies, horses with RAO had significantly lower levels of AA in both plasma and bronchoalveolar lavage compared to healthy horses. The results of the statistical analysis confirmed the relationship between the number of neutrophils in bronchoalveolar lavage fluid and the level of AA $(\mathrm{P}<0.001)$ in the group of horses with RAO. Neutrophils may affect the level of AA by inducing oxidation that occurs as a result of ROS production (53).

Exposure to ozone causes a series of reactions in the human respiratory tract, including pulmonary function inhibition and causing airway inflammation (54). Ozone in the upper and lower respiratory tract reacts with unsaturated fatty acids, proteins, and antioxidants, such as ascorbic acid and reduced glutathione (55). The effects of ozone on the respiratory system's response in the horse were researched by Deaton et al. (56). Their results indicated that horses with RAO that are not in the remission phase are not more sensitive to the compound's activity compared with clinically healthy horses. The concentration of AA, amino acid redox ratio (AARR), UA, GSH, GSSG and GRR did not differ significantly between the group of healthy horses and those suffering from RAO before ozone exposure, and the concentration did not change after animal exposure to the compound. A significant part of the administered ozone reacts with a variety of compounds, most likely with fats and proteins (24, 55), which reduces its potentially harmful effects. It is possible that the doses and time points that authors selected were not optimal for assessing the effects of $\mathrm{O}_{3}$ on antioxidants $(57,58)$. RAO-affected horses in remission are not more sensitive to ozone despite a decreased pulmonary antioxidant capacity. Sensitivity to ozone appears to be independent of initial pulmonary antioxidant status.

\section{EXPOSURE TO MOLDY HAY AND MYELOPEROXIDASE CONCENTRATION}

Myeloperoxidase (MPO) is a haemoprotein stored within the granulocytes, catalyzing the formation of hypochlorous acid which has oxidizing properties. Its level in tissues and body fluids has been studied in humans and experimental animals. It can be used to determine the level of degranulation and activation of neutrophils (59, 60). Myeloperoxidase levels in bronchoalveolar lavage in horses were described as the first by Art et al. (61). In horses with RAO, exposure to moldy hay caused a significant increase in the number of neutrophils and MPO concentration in 
bronchoalveolar lavage fluid. After 2 months of grazing, lung function returned to physiological values, and the number of neutrophils and the concentration of MPO significantly decreased. Although there was no significant difference in the number of neutrophils in bronchoalveolar lavage fluid between a group of healthy horses and those with RAO during remission, it was noted that the level of MPO in horses with RAO during remission was significantly higher than in the clinically healthy horses. This relationship shows that inflammatory cells, neutrophils in this case, are able to maintain an increased level of activation for a long time (at least two months) after exposure to environmental irritants (61).

\section{THE ENZYME TRIAD IN RAO}

There are very few publications found in the scientific literature related to RAO in horses about the most important line of defence against free radicals, namely the enzyme triad. Their most important function is to prevent the formation of ROS and their reactions with biologically important compounds. Antioxidant enzymes in horse pathology have been described, among others, in the course of oxidative stress following $(62,63)$. Authors compare enzyme activity in a group of horses with RAO and those clinically healthy (64). The results of these studies showed a significantly impaired activity of antioxidant enzymes in horses with clinical form of RAO. This condition indicates intensified formation of free radicals and their active participation in the pathogenesis of recurrent airway obstruction. Some studies showed a statistically significant increase in the activity of antioxidant enzymes in ill horses, while other studies showed a decrease in activity of these enzymes $(18,22)$. Inconsistent results may be associated with the exacerbation of symptoms, horse maintenance or any treatment administered (1). High activity of antioxidant enzymes in different studies and low in others suggested that redox system is upregulated during exposure to dusty straw and hay to combat oxidative stress $(22,65)$. Ramery et al. (66) proposed distinct mechanisms to explain local and systemic oxidative stress related to airway inflammation. Local oxidative stress occurring in the lung is induced by inflammatory cytokines such as TNF and IL1, and by respiratory burst by activated macrophages and neutrophils (67). The mechanism proposed for systemic oxidative stress involves intermittent hypoxia which activates systemic NOX and other ROS-producing enzymes (68). Whether changes of GPx activity in peripheral whole blood have potential in diagnosis and monitoring of IAD in horses needs to be investigated in future studies evaluating sensitivity and specificity, and predictive value.

\section{CONCLUSION}

Recurrent airway obstruction (RAO) is currently one of the most frequently encountered pathologies in the horse. Production of reactive oxygen species is a secondary phenomenon to the disease. Numerous studies point to the deregulation of the activity and synthesis of antioxidants in the course of RAO. Chronic inflammation intensifies ROS generation, which determines oxidative stress and exhaustion of reserves of antioxidants in the body. The severity of symptoms, animal maintenance and pharmacological therapy are associated with the level of free radical formation. The use of oral supplementation with antioxidants appears to be justified in order to maintain the oxidative and antioxidative balance. Studies are being conducted now to better define the role of antioxidant enzymes in the course of RAO in horses.

\section{REFERENCES}

1. Niedźwiedź, A., Nicpoń, J., Różycki, P. (2006). Pathogenesis, diagnosis and treatment of Recurrent Equine Airway. Med. Wet. 5, 512-515.

2. McPherson, E. A., Lawson, G. H., Murphy, J. R., Nicholson, J. M., Fraser, J. A., Breeze, R. G., Pirine, H. M. (1978). Chronic obstructive pulmonary disease (COPD) identification of affected horses. Equine Vet. J. 10, 47-53.

http://dx.doi.org/10.1111/j.2042-3306.1978.tb02215.x PMid:631106

3. Niedźwiedź, A, Jaworski, Z, Kubiak, K. (2014). Circulating immune complexes and markers of systemic inflammation in RAO-affected horses. Pol. J. Vet. Sci. 17, 697-702. http://dx.doi.org/10.2478/pjvs-2014-0101

4. Commoner, B., Townsend, J., Pake, G. E. (1954). Free radicals in biological materials. Nature 174, 689-691. http://dx.doi.org/10.1038/174689a0 PMid:13213980

5. Harman,D.(1956). Aging: a theorybased on freeradical and radiation chemistry. J. Gerontol. 11, 298-300. http://dx.doi.org/10.1093/geronj/11.3.298 PMid:13332224 
6. Bannister, W. H. (1988). From haemocuprein to copper-zinc superoxide dismutase: a history on the fiftieth anniversary of the discovery of haemocuprein and the twentieth anniversary of the discovery of superoxide dismutase. Free Radic. Res. Commun. 5, $35-42$.

http://dx.doi.org/10.3109/10715768809068556 PMid:3069613

7. Zawadzki, M., Pawlas, K., Niedźwiedź, A., Murawska-Ciałowicz, E., Januszewska, L., Nicpoń, J. (2008). Ewaluation of oxidative stress in manganum intoxication rat's barins. Medycyna Wet. 6, 836-840.

8. Chelikani, P., Fita, I., Loewen, P.C. (2004). Diversity of structures and properties among catalases. Cellular and Molecular Life Sciences 61, 192-208. http://dx.doi.org/10.1007/s00018-003-3206-5 PMid:14745498

9. Cadenas E. (1997). Basic mechanism of antioxidant activity. BioFactors 6: 391-397.

10. Epp, O., Ladenstein, R., Wendel, A. (1983). The refined structure of the selenoenzyme glutathione peroxidase at $0.2-\mathrm{nm}$ resolution. Eur. J. Biochem. 133, 51-69.

http://dx.doi.org/10.1111/j.1432-1033.1983.tb07429.x PMid:6852035

11. Heffner, J. E., Repine, J. E. (1989). Pulmonary strategies of antioxidant defense. Am. Rev. Respir:. Dis. $140,531-554$.

http://dx.doi.org/10.1164/ajrccm/140.2.531 PMid:2669581

12. Baldwin, S.R., Grum, C.M., Boxer, L.A., Simon, R.H., Ketai, L. H., Devall, L. H. (1986). Oxidant activity in expired breath of patients with adult respiratory distress syndrome. Lancet 1, 11-13. http://dx.doi.org/10.1016/S0140-6736(86)91895-7

13. Barnes, P. J. (1990). Reactive oxygen species and airway inflammation. Free Radic. Biol. Med. 9, 235-243.

http://dx.doi.org/10.1016/0891-5849(90)90034-G

14. Cantin, A.M., Crystal, R.G. (1985). Oxidants, antioxidants and the pathogenesis of emphysema. Eur: J. Respi. Dis. 66, 7-17.

15. Kirschvink, N., Reinhold, P. (2008). Use of alternative animals as asthma models. Curr Drug Targets 9, 470-484.

http://dx.doi.org/10.2174/138945008784533525

PMid:18537586

16. Art, T., Kirschvink, N., Smith, N., Lekeux, P. (1999). Indices of oxidative stress in blood and pulmonary epithelium lining fluid in horses suffering from recurrent airway obstruction. Equine. Vet. J. 31, 397-401.

http://dx.doi.org/10.1111/j.2042-3306.1999.tb03839.x PMid:10505955
17. Kirschvink, N., Smith, N., Fievez, L. (2002). Effect of chronic airway inflammation and exercise on pulmonary and systemic antioxidant status of healthy and heaves-affected horses. Equine Vet. J. 34, 563-571.

http://dx.doi.org/10.2746/042516402776180223 PMid:12357995

18. Niedźwiedź, A., Jaworski, Z. (2014). Oxidantantioxidant status in the blood of horses with symptomatic recurrent airway obstruction (RAO). J. Vet. Intern. Med. 28, 1845-1852. http://dx.doi.org/10.1111/jvim.12452 PMid:25231643

19. Art, T., Kirschvink, N., Smith, N., Lekeux, P. (1999). Indices of oxidative stress in blood and pulmonary epithelium lining fluid in horses suffering from recurrent airway obstruction. Equine Vet. J. 31, 397-401.

http://dx.doi.org/10.1111/j.2042-3306.1999.tb03839.x PMid:10505955

20. Olszweski, M. A., Laber, G. (1993). Production of free oxygen radicals by phagocytes from respiratory tract lavaged as well as from peripheral blood of horses with Chronic Obstructive Pulmonary Disease (COPD) in comparison to healthy animals. Wien. Tierdrztl. Msch. 332-337.

21. Klaveren, R. J. van Demedts, M., Nemery, B. (1997). Cellular glutathione turnover in vitro, with emphasis on type 11 pneumocytes. Eu. Respir. J. 10, 1392-1400. http://dx.doi.org/10.1183/09031936.97.10061392

22. Kirschvink, N., Smith, N., Fievez, L., Bougnet, V., Art, T., Degand, G., Marlin, D., Roberts, C., Genicot, B., Lindsey, P., Lekeux, P. (2002). Effect of chronic airway inflammation and exercise on pulmonary and systemic antioxidant status of healthy and heaves-affected horses. Equine Vet. J. 34, 563-571.

http://dx.doi.org/10.2746/042516402776180223 PMid:12357995

23. Harris, R. C., Marlin, D. J., Snow, D. H., Harkness, R. A. (1991). Muscle ATP loss and lactate accumulation at different work intensities in the exercising Thoroughbred horse. Eur. J. Appl. Physiol. 62, 235-244. http://dx.doi.org/10.1007/BF00571546

24. Rahman, I., Swarska, E., Henry, M., Stolk, J., MacNee, W. (2000). Is there any relationship between plasma antioxidant capacity and lung function in smokers and in patients with chronic obstructive pulmonary disease? Thorax 55, 189-193. http://dx.doi.org/10.1136/thorax.55.3.189 PMid:10679536 PMCid:PMC1745692

25. Smith, L. J., Houston, M., Anderson, J. (1993). Increased levels of glutathione in bronchoalveolar lavage fluid from patients with asthma. Am. Rev. Respir. Dis. 147, 1461-1464. http://dx.doi.org/10.1164/ajrccm/147.6_Pt_1.1461 PMid:8503557 
26. Kodavanti, U. P., Costa, D. L., Richards, J., Crissman, K. M., Slade, R., Hatch, G. E. (1996). Antioxidants in bronchoalveolar lavage fluid cells isolated from ozoneexposed normal and ascorbatedeficient guinea pigs. Expt. Lung Res. 22, 435-448. http://dx.doi.org/10.3109/01902149609046034

27. Rautalahti, M., Virtamo, J., Haukka, J., Heinonen, O.P., Sundvall, J., Albanes, D., Huttunen, J.K. (1997). The effect of alpha-tocopherol and beta-carotene supplementation on COPD symptoms. Am. J. Respir. Crit. Care Med. 156, 1447-1452. http://dx.doi.org/10.1164/ajrccm.156.5.96-11048 PMid:9372659

28. Grievink, L., Smit, H.A., Ocké, M.C., van t'Veer, P., Kromhout, D. (1998). Dietary intake of antioxidant (pro-) vitamins, respiratory symptoms and pulmonary function: the MORGEN study. Thorax 53, 166-171. http://dx.doi.org/10.1136/thx.53.3.166 PMid:9659349 PMCid:PMC1745167

29. MacNee, W., Rahman, I. (1999). Oxidants and antioxidants as therapeutic targets in chronic obstructive pulmonary disease. Am. J. Respir. Crit. Care Med. 160, 58-65. http://dx.doi.org/10.1164/ajrccm.160.supplement_1.15 PMid:10556172

30. Forastiere, F., Pistelli, R., Sestini, P., Fortes, C., Renzoni, E., Rusconi, F., Dell'Orco, V., Ciccone, G., Bisanti, L. (2000). Consumption of fresh fruit rich in vitamin $\mathrm{C}$ and wheezing symptoms in children. SIDRIA Collaborative Group, Italy (Italian Studies on Respiratory Disorders in Children and the Environment). Thorax 55, 283-288.

http://dx.doi.org/10.1136/thorax.55.4.283

PMCid:PMC1745721

31. Kirschvink, N., Fievez, L., Bougnet, V., Art, T., Degand, G., Smith, N., Marlin, D., Roberts, C., Harris, P., Lekeux, P. (2002). Effect of nutritional antioxidant supplementation on systemic and pulmonary antioxidant status, airway inflammation and lung function in heaves-affected horses. Equine Vet J. 34, 705-712.

http://dx.doi.org/10.2746/042516402776250298 PMid:12455842

32. Essén-Gustavsson, B., Gottlieb-Vedi, M., Lindholm, A. (1999). Muscle adenine nucleotide degradation during submaximal treadmill exercise to fatigue. Equine Vet J. Suppl. 30, 298-302.

PMid:10659272

33. Mills, P.C., Smith, N.C., Harris, R.C., Harris, P. (1997). Effect of allopurinol on the formation of reactive oxygen species during intense exercise in the horse. Res Vet Sci. 62, 11-16. http://dx.doi.org/10.1016/S0034-5288(97)90172-7
34. Heunks, L.M.A., Vina, J., van Herwaarden, C.L., Folgering, H.T.M., Gimeno, A., Dekhuijzen, P.N. (1999). Xanthine oxidase is involved in exerciseinduced oxidative stress in chronic obstructive pulmonary disease. Am. J. Physiol. 277, 1697-1704.

35. Youssef, M.A., El-khodery, S.A., Ibrahim, H.M. (2013). Effect of selenium and vitamin c on clinical outcomes, trace element status, and antioxidant enzyme activity in horses with acute and chronic lower airway disease. A randomized clinical trial. Biol Trace Elem Res. 152, 333-342.

http://dx.doi.org/10.1007/s12011-013-9636-5

PMid:23479319

36. Kirschvink, N., de Moffarts, B., Lekeux, P. (2008). The oxidant/antioxidant equilibrium in horses. Vet $\mathrm{J}$. 177, 178-191.

http://dx.doi.org/10.1016/j.tvj1.2007.07.033 PMid:17897849

37. Jain, SK, Mcvie, R, Smith, T. (2000). Vitamin $\mathrm{E}$ supplementation restores glutathione and malondialdehyde to normal concentrations in erythrocytes of type 1 diabetic children. Diabetes Care 23, 1389-1394.

http://dx.doi.org/10.2337/diacare.23.9.1389 PMid:10977039

38. Johnson, K. (2006). Effects of vitamin E supplementation on oxidative stress parameters measured in exercising horses. Doctoral dissertation. University of Florida

39. Matera, M.G., Calzetta, L., Peli, A., Scagliarini, A., Matera, C., Cazzola, M. (2005). Immune sensitization of equine bronchus: glutathione, IL-1 expression and tissue responsiveness. Respiratory Research 6, 104. http://dx.doi.org/10.1186/1465-9921-6-104 PMid:16164745 PMCid:PMC1261534

40. Rahman, I., MacNee, W. (2000). Regulation of redox glutathione levels and gene transcription in lung inflammation: therapeutic approaches. Free Radic Biol Med. 28:, 1405-1420. http://dx.doi.org/10.1016/S0891-5849(00)00215-X

41. Rahman, I. (2002). Oxidative stress and gene transcription in asthma and chronic obstructive pulmonary disease: antioxidant therapeutic targets. Curr Drug Targets Inflamm Allergy, 1, 291-315. http://dx.doi.org/10.2174/1568010023344607 PMid:14561194

42. Vengopual, C., Mariappan, N., Holmes, E., Kearney, M., Beadle, R. (2013). Effect of potential therapeutic agents in reducing oxidative stress in pulmonary tissues of recurrent airway obstructionaffected and clinically healthy horses Equine Vet $\mathrm{J}$. $45,80-84$.

http://dx.doi.org/10.1111/j.2042-3306.2012.00566.x PMid:22506732 
43. Cortijo, J., Bou, J., Beleta, J., Cardelus, I., Llenas, J., Morcillo, E., Gristwood, R.W. (1993). Investigation into the role of phosphodiesterase IV in bronchorelaxation, including studies with human bronchus. Br. J. Pharmacol. 108, 562-568. http://dx.doi.org/10.1111/j.1476-5381.1993.tb12841.x PMid:8383567 PMCid:PMC1907986

44. Zhang, J., Xu, Z., Zhang, C., Dail, H., Jil, X., Wang, X., Lil, C. (2011). Pyrrolidine dithiocarbamate inhibits nuclear factor-kB pathway activation, and regulates adhesion, migration, invasion and apoptosis of endometriotic stromal cells. Mol Hum Reprod. 17, 175-181.

http://dx.doi.org/10.1093/molehr/gaq090

PMid:21030494

45. Granström, B.W., Xu, C.B., Nilsson, E., Bengtsson, U.H., Edvinsson, L. (2004). Up-regulation of endothelin receptor function and mRNA expression in airway smooth muscle cells following Sephadexinduced airway inflammation. Basic Clin Pharmacol Toxicol. 95, 43-48.

http://dx.doi.org/10.1111/j.1742-7843.2004. pto950109.x

PMid:15245576

46. Hay, D.W., Goldie, R.G. (1998). Potential pathophysiological role of endothelin-1 in asthma. Drug News Perspect 11, 411-418.

http://dx.doi.org/10.1358/dnp.1998.11.7.660500

PMid:15616682

47. Leguillette, R., Desevaux, C., Lavoie, J. (2002). Effects of pentoxifylline on pulmonary function and results of cytological examination of bronchoalveolar lavage fluid in horses with recurrent airway obstruction. Am J Vet Med. 63, 459-463.

48. Mudway, I. S., Krishna, M. T., Frew, A. J. et al. (1999). Compromised concentrations of ascorbate in fluid lining the respiratory tract in human subjects after exposure to ozone. Occup Environ Med. 56, 473-481. http://dx.doi.org/10.1136/oem.56.7.473 PMid:10472319 PMCid:PMC1757764

49. Thomas, E. L., Learn, D. B., Jefferson, M. M. (1999). Superoxidedependent oxidation of extracellular reducing agents by isolated neutrophils. J Biol Chem. 263, 2178-2186.

50. Bielory, L., Gandhi, R. (1994). Asthma and vitamin C. Ann Allergy 73, 89-96.

PMid:8067602

51. Schunemann, H. J., Freudenheim, J. L., Grant, B.J. (2001). Epidemiologic evidence linking antioxidant vitamins to pulmonary function and airway obstruction. Epidemiol Rev. 23, 248-267.

http://dx.doi.org/10.1093/oxfordjournals.epirev. a000805

PMid:12192736
52. Deaton, C. M., Marlin, D. J., Smith, N. C., Harris, P. A., Roberts, C. A., Schroter, R. C., Kelly, F. J. (2004). Pulmonary epithelial lining fluid and plasma ascorbic acid concentrations in horses affected by recurrent airway obstruction. AJVR 65 , 80-87.

http://dx.doi.org/10.2460/ajvr.2004.65.80

53. Bigley, R. H., Stankova, L. (1974). Uptake and reduction of oxidized and reduced ascorbate by human leukocytes. J. Exp. Med. 139, 1084-1092.

http://dx.doi.org/10.1084/jem.139.5.1084

PMid:4825242 PMCid:PMC2139671

54. Mudway, I.S., Kelly, F.J. (2000). Ozone and the lung: a sensitive issue. Mol Aspects Med. 21, 1-48. http://dx.doi.org/10.1016/S0098-2997(00)00003-0

55. Pryor, W. A., Das,. B., Church, D. F. (1991). The ozonation of unsaturated fatty acids: aldehydes and hydrogen peroxide as products and possible mediators of ozone toxicity. Chem. Res. Toxicol. 4, 341-348. http://dx.doi.org/10.1021/tx00021a014 PMid:1912318

56. Deaton, C. M., Marlin, D. J., Smith, N. C., Roberts, C. A. , Harris, P. A. , Schroter, R. C., Kelly, F. J. (2005). Antioxidant and inflammatory responses of healthy horses and horses affected by recurrent airway obstruction to inhaled ozone. Equine Vet J. 37, 243-249

http://dx.doi.org/10.2746/0425164054530605

PMid:15892234

57. Kari, F., Hatch, G., Slade, R., Crissman, K., Simeonova, P.P., Luster, M. (1997). Dietary restriction mitigates ozone-induced lung inflammation in rats: a role for endogenous antioxidants. Am J Respir Cell Mol Biol. 17, 740-747.

http://dx.doi.org/10.1165/ajrcmb.17.6.2844 PMid:9409561

58. Long, N. C., Suh, J., Morrow, J. D., Schiestl, R. H., Murthy, G. G., Brain, J. D., Frei, B. (2001). Ozone causes lipid peroxidation but little antioxidant depletion in exercising and nonexercising hamsters. J. Appl. Physiol. 91, 1694-1700.

PMid:11568152

59. Krawisz, J. E., Sharon, P., Stenson, W. F. (1984). Quantitative assay for acute intestinal inflammation based on myeloperoxidase activity. Assessment of inflammation in rat and hamster models. Gastroenterology 87, 1344-1350. PMid:6092199

60. Weiland, J. E., Davis, W. B., Holter, J. F., Mohammed, J. R., Dorinsky, P. M., Gadek, J. E. (1986). Lung neutrophils in the adult respiratory distress syndrome. Clinical and pathophysiologic significance. Respir Dis. 133, 218-225. 
61. Art, T., Franck, T., Lekeux, P., de Moffarts, B., Couëtil, L., Becker, M., Kohnen, S., Deby-Dupont, G., Serteyn, D. (2006). Myeloperoxidase concentration in bronchoalveolar lavage fluid from healthy horses and those with recurrent airway obstruction. The Canadian Journal of Veterinary Research 70, 291-296. PMid:17042382 PMCid:PMC1562538

62. Niedźwiedź, A., Filipowski, H., SłużewskaNiedźwiedź, M., Nicpoń, J. (2011). Stress level in horses during transport as a variable in Krefft's function. Medycyna Wet. 67, 270-274.

63. Niedźwiedź, A., Nicpoń, J., Zawadzki, M., Słuzewska-Niedźwiedź, M., Januszewska, L. (2012). The influence of road transport on the activities of glutathione reductase, glutathione peroxidase, and glutathione-S-transferase in equine erythrocytes. Vet Clin Pathol. 41, 123-126.

http://dx.doi.org/10.1111/j.1939-165x.2011.00396.x

64. Niedźwiedź, A., Nicpoń, J., Borowicz, H, Łoś, P., Zawadzki, M., Januszewska, L. (2011). Evaluation of selected antioxidant enzymes in the blood of horses with recurrent airways obstruction. Medycyna Wet. 67, 129-132.
65. Tan, R.H., Thatcher, C.D., Buechner-Maxwell, V., Christmann, U., Crisman, M.V., Were, S.R., (2010). Measurement of ascorbic acid concentration and glutathione peroxidase activity in biological samples collected from horses with recurrent airway obstruction. Am J Vet Res. 71, 1500-1507. http://dx.doi.org/10.2460/ajvr.71.12.1500 PMid:21118003

66. Ramery, E., Fraipont, A., Richard, E.A., Art, T., Pirottin, D., van Delm, W., Bureau, F., Lekeux, P. (2015). Expression microarray as a tool to identify differentially expressed genes in horses suffering from inflammatory airway disease. Vet Clin Pathol. 44, 37-46.

http://dx.doi.org/10.1111/vcp.12216

PMid:25488254

67. Quinlan, T., Spivack, S., Mossman, B.T. (1994). Regulation of antioxidant enzymes in lung after oxidant injury. Environ Health Perspect. 102, 79-87. http://dx.doi.org/10.1289/ehp.9410279 PMid:7523104 PMCid:PMC1567078

68. Dumitrascu, R., Heitmann, J., Seeger, W., Weissmann, N., Schulz, R. (2013). Obstructive sleep apnea, oxidative stress and cardiovascular disease: lessons from animal studies. Oxid Med Cell Longev. http://dx.doi.org/10.1155/2013/234631 PMid:23533685 PMCid:PMC3603718 